\title{
„Stručná historie Literatury české“، K osudu nevydané učebnice rajhradského benediktina Bedy Dudíka k dějinám české literatury z roku $1847^{1}$
}

Richard MAHEL

\author{
ARTICLE INFO \\ Article history: \\ Received 13 March 2020 \\ Accepted 31 August 2020 \\ Available online 31 \\ December 2020 \\ Keywords: \\ education, history, \\ textbook, Czech language \\ and literature, Moravia, \\ $19^{\text {th }}$ century \\ R. Mahel \\ Národní archiv • \\ Archivní 2257/4 \\ 14900 Praha 4 • \\ Česká republika • \\ mahel.richard@centrum.cz
}

\begin{abstract}
"Brief history of the Czech Literature". On the fate of an unpublished textbook about history of the Czech literature from 1847 by the Benedictine Beda Dudik from Rajhrad

In the years 1841-1854 the Benedictine Beda Dudík (1815-1890) worked as a teacher at the Episcopal Institute of Philosophy in Brno and then at the Higher Grammar School in Brno. As a teacher and a supporter of a development of the Czech national movement in Moravia he strove for the introduction of teaching of the Czech language and literature in the Moravian church education. He succeeded in his efforts and the Court study commission and the Episcopal ordinariate in Brno permitted teaching of the Czech language within the school curriculum of the Institute of Philosophy. For the successful completion of the teaching, Dudik compiled a textbook for his students about history of the Czech language and book writing and he intended to publish it in print at "Matice česká" in Prague. The textbook was approved successfully in a censorship procedure; however, it was not finally published in print due to disagreements with the authors of the compiled works. Nevertheless, it was significant for the development of national efforts in Moravia and it, first and foremost, revealed the young Beda Dudík as a great supporter of the then minority Czech national movement in Moravia, which changed later when he left his pedagogical experience in favour of his better-known historiographical, official and diplomatic practice.
\end{abstract}

Beda Dudík (1815-1890) zahájil svou pedagogickou dráhu v ř́ínu roku 1840 na biskupském Filozofickém ústavu v Brně, kde před několika lety sám studoval. Postavení na škole si vybudoval v letech 1841-1842, kdy se postupně ze suplenta latiny a řečtiny stal učitelem dějepisu, zeměpisu a celé ústavní katedry (Lehrkanzel) klasické filologie. Jeho působení bylo usnadněno též skutečností, že byl konventuálem benediktinského řádu v Rajhradu, z jehož

\footnotetext{
${ }^{1}$ Př́íspěvek vychází ze zpracování dané problematiky v monografii věnované životu, historiografickému dílu a odborné činnosti moravského historiografa Františka Bedy Dudíka (MAHEL, Richard, 2015. Beda Dudik (1815-1890). Život a dílo rajhradského benediktina a moravského zemského historiografa ve svétle jeho osobní pozůstalosti. Praha: Národní archiv, s. 135, 167-176, 312-313) a z dochovaných rukopisů Dudíkovy pojednané učebnice $\mathrm{z}$ roku 1847.
} 
komunity, podobně jako z premonstrátské kanonie $\mathrm{v}$ Nové Říši a augustiniánského kláštera u svatého Tomáše na Starém Brně, se přednostně vybírali učitelé obou brněnských biskupských ústavů. Beda Dudík působil v moravském školství téměř patnáct let, $\mathrm{z}$ toho devět let na Filozofickém ústavu a šest let na Vyšším gymnáziu v Brně, takže o něm lze říci, že byl nakonec zkušeným a úspěšným pedagogem, na něhož řada jeho žáků později ráda vzpomínala. $^{2}$ Dudíkovo pedagogické působení bylo navíc spojeno $\mathrm{s}$ jeho tehdejší jednoznačnou podporou českého národního hnutí v Čechách a jeho recepcí na Moravě, stejně jako s obdivem knové koncepci českých národních dějin $\mathrm{z}$ pera českého historiografa Františka Palackého $(1798-1876),{ }^{3}$ což se postupně změnilo až v době Dudíkova převažujícího historiografického působení jako zaměstnance zemských stavů, přibližně od padesátých let 19. století, kdy se nechával znovu inspirovat zemským, nově ale i rakouským státním patriotismem, př́značně nazývaným rakušanství. ${ }^{4} \mathrm{~V}$ letech $1847-1848$, o která se nám nejvíce jedná, byl však mladý Dudík stále ještě zasažen, jako řada jeho současníků v biskupských alumnátech a na teologických školách, rozvíjejícím se slovanstvím a českým národním hnutím, na Moravě prozatím pěstovaném ve výrazně skromnějším formátu, než tomu bylo v sousedních Čechách. To tehdy zanechalo svůj odraz také v Dudíkově výuce, zejména $\mathrm{v}$ dějepisných přednáškách, ve kterých často odbíhal od předepsaných osnov, což občas vyvolávalo neshody s jeho nadřizenými, zejména pak stížnosti u brněnského biskupa Antonína Arnošta hraběte Schaffgotsche (v úřadu 1841-1870). Jiným dobovým exemplárním projevem radikálního smýšlení u nižšího duchovenstva byl Dudíkův požadavek na zavedení výuky „českoslovanskému“ jazyku a literatuře v moravském školství. Tady si však Dudík počínal daleko věcněji i pragmatičtěji, díky čemuž nakonec dosáhl svého cíle.

Dudíkova původní žádost, podávaná ještě jen z vlastní iniciativy, byla úspěšná pouze částečně, když dne 28. prosince 1845 , přibližně měsíc a půl od vlastního podání, mu bylo dekretem biskupského studijního komisaře Václava rytíře Tálského (1781-1854) umožněno realizovat soukromou a bezplatnou výuku českého jazyka, mimo schválené školní osnovy biskupského ústavu. ${ }^{5}$ Teprve druhá Dudíkova žádost z jara roku 1846, k níž přiložil osvědčení

\footnotetext{
${ }^{2}$ Blíže: MAHEL, Richard, 2018. „Pilně snáším stavivo $\mathrm{k}$ příští budově, jako učitel mám $\mathrm{k}$ tomu př́ležitostí dost“. K pedagogickému působení rajhradského benediktina Bedy Dudíka v Brně (1841-1854) v čase vzepětí českého národně emancipačního hnutí. In: KAŠPÁRKOVÁ, Šárka a kol., eds. Morava v době převratů a změn 1848-1918. Sborník př́spěvků z mezinárodní odborné konference, Kroměříž, 6. a 7. června 2018. Kroměříž: Knihovna Kroměřížska, s. 91-105, týž, 2015. Beda Dudík (1815-1890). Život a dílo rajhradského benediktina a moravského zemského historiografa ve světle jeho osobni pozi̊stalosti. Praha: Národní archiv, s. 126-159.

${ }^{3}$ K němu bliže: KOŘALKA, Jiří, 1998. František Palacký (1798-1876). Životopis. Praha: Argo, 661 s., týž, 2006. Rodem Moravan, národem Čech. František Palacký. In: JAN, Libor a DRAHOŠ, Zdeněk, eds. Osobnosti moravských dějin (1). Brno: Matice moravská, s. 309-329; ŠTAIF, Jiří, 2009. František Palacký. Život, dílo, mýtus. Praha: Vyšehrad, $368 \mathrm{~s}$.

${ }^{4}$ Blíže: MAHEL, Richard, 2017. Střetávání zemského patriotismu, národně orientovaného vlastenectví a multinacionálního státního patriotismu v korespondenci a v odborném díle moravského historika Bedy Dudíka. In: Laudatio PhDr. Evě Ryšavé. Př́spěeky k životnímu jubileu. Acta Musei nationalis Pragae, Historia litterarum 62, č. 1-2, s. 26-40. - K uvedené státněpolitické ideologii blíže např.: KÁRNÍK, Zdeněk, 1998. Konzervativní sociální zdroje supraetnického rakušanství a předlitavského supranacionalismu. In: K novověkým sociálním dějinám českých zemí. Díl 2: Z dob rakouských a předlitavských, 1848-1918. Praha: Karolinum, s. 49-85.

${ }^{5}$ Dekret datovaný 28. 12. 1845 v Brně, podeps. V. Tálským. Fond E6 (Benediktini Rajhrad), inv. č. 1947, sign. Dm 3/1-6, ka 151, f. 9. MZAB, Brno.
} 
olomouckého profesora češtiny Aloise Vojtěcha Šembery, vedla k vydání druhého dekretu z 22. března 1846, který byl vzhledem k podané žádosti daleko vstřícnější. ${ }^{6}$ Ač stále bezplatně, umožnil Dudíkovi pořádat veřejné přednášky na půdě ústavu dvakrát týdně (v pondělí a ve čtvrtek), s právem výstupní veřejné zkoušky a s vydáváním platného vysvědčení. Na základě dekretu tak mohl zahájit veřejnou výuku českého jazyka a literárnímu knihopisu, která začala slavnostním Dudíkovým nástupním projevem, jak se také slušelo na významnou změnu v jinak konzervativních osnovách biskupského Filozofického ústavu. ${ }^{7}$

Dudík však postrádal vhodnou učebnici ke svému jazykovědnému záměru. Existovaly sice mnohé soupisy knihopisu, jazykové př́ručky a slovníky, dokonce i jazykové učebnice, mnohé z nich však byly podle rajhradského benediktina nepoužitelné. Bud' kvůli svému obsahu a zaměření, ${ }^{8}$ ideologickému vyústění ${ }^{9}$, nebo kvůli svému určení a použitému jazyku (němčině). ${ }^{10}$ Zpočátku tak byli jeho studenti závislí pouze na jeho přednáškách. To se nejprve pokusil vyřešit organickým doplňováním stávající školní knihovny, zejména o slovanské tituly a učebnice jiných pedagogů, kteří se výuce českého jazyka již dřive či v dané chvíli věnovali. $\mathrm{V}$ tomto ohledu kontaktoval např́klad i seminaristu Královéhradeckého semináře Antonína Hrušku, který Dudíkovi slíbil obstarat a zaslat řadu česky psaných národně orientovaných učebnic a jiných tisků. ${ }^{11}$ Nakonec se rajhradský benediktin odhodlal k poměrně odvážnému kroku s nejistým cílem: sepsat učebnici vlastní, která by obsahovala v bilančním i výčtovém přehledu pro výuku vše podstatné, včetně rodícího se konceptu české národní identity v sousedních Čechách. Výsledek pak hodlal nabídnout svým studentům a současně předpokládal, že po úspěšném cenzurním řízení bude jazyková učebnice následně vydána tiskem nákladem Matice české v Praze, jako vlastenecký počin přicházející z Moravy.

Je třeba ř́ci, že čeština, i přes germanizační tlak a unifikační snahy ústředních rakouských vlád v 18. a 19. století, zcela z oblasti školství a vzdělávání nezmizela. Udržela se v českých zemích na některých univerzitních oborech a $\mathrm{v}$ př́ślušných přednáškách (např̀. $\mathrm{v}$ medicíně, u pastorální teologie, zřízením katedry české řeči a literatury na pražské univerzitě v roce 1793 apod.), později na některých českých gymnáziích, na stavovské akademii v Olomouci a především na vídeňském Theresianu (již od roku 1755). Přechodně také na stavovské vojenské akademii ve Vídni (1754-1769) a naopak dlouhodobě na vídeňské univerzitě (od roku 1775). Čeština byla zaznamenána dále na vídeňské inženýrské akademii (zejména

\footnotetext{
${ }^{6}$ Dekret datovaný 22. 3. 1846 v Brně, podeps. V. Tálským. Tamtéž, f. 10. MZAB, Brno.

${ }^{7}$ Blíže: POKORNÝ, Václav Jan, 1922. Beda Dudík zahajuje přednášky o české literatuře v Brně roku 1846. Archiv literární: prameny dějin české literatury katolické: př́loha $k$ revui Archa. Olomouc: Družina literární a umělecká. Sv. II, s. 201-204.

${ }^{8}$ Např. v př́padě jazykových „odborných“ aktivit Františka Dominika Trnky a jeho soukromého brněnského ústavu českého jazyka nebo diskutabilních pokusů Václava Štacha a Tomáše Fryčaje obohatit jazyk dialekty.

${ }^{9}$ Např. KLÁCEL, František Matouš, 1843. Počátky wédecké mluwnictví českého. Brno: K. Winiker, 123 s., které bylo od počátku považováno za dílo koncepčně i metodicky pochybené, odmítnuté vlasteneckou obcí.

${ }^{10}$ Napřr. ZIAK, Vincenc Paul, 1842. Böhmische Sprachlehre für Deutsche. Brünn. 440 s., MACHÁČ́EK, Simeon Karel, 1830. Bömische Chrestomathie für Deutsche. Mit Erläuterungen und einem vollständigen Wörterbuch. Prag, $271+125$ s., TOMEK, Václav Vladivoj, 1848. Kurzgefasste böhmische Sprachlehre für Böhmen. Prag: J. Calve, $86 \mathrm{~s}$.

${ }^{11}$ Dopis A. Hrušky B. Dudíkovi, datovaný 5. 12. 1847 v Hradci Králové. Fond E6, inv. č. 1948, sign. Dm 3/2a94, ka 153, f. 391. MZAB, Brno.
} 
v letech 1785-1814) a počínaje rokem 1808 i na Reálné škole při polytechnickém institutu. Ještě před zahájením Dudíkovy pedagogické praxe se výuce češtiny věnovali soukromě někteří významní jazykovědci či učitelé. Kromě exjezuity a pedagoga Josefa Dobrovského (1753-1829), ${ }^{12}$ který češtinu soukromě vyučoval na generálním semináři v klášterním Hradisku u Olomouce, se jí v brněnském alumnátu věnoval kněz a pedagog František Sušil (1804-1868), ${ }^{13}$ zakladatel tzv. Družiny Sušilovy, dále češtinu učil olomoucký vikář a pozdější probošt v Dubě Jarolím Lysek, od roku 1849 dokonce veřejně na německém gymnáziu v Olomouci, dále na olomoucké univerzitě jako suplent lékař a novinář Jan Evangelista Helcelet (1812-1876) ${ }^{14}$ v letech 1848-1849 a prímo na brněnském Filozofickém ústavu soukromě kněz a profesor pastorálky na teologické fakultě v Olomouci Jan Evangelista Mácha (1798-1845) v letech 1838-1845. Dá se tak říci, že Dudík na činnost předchůdců, zejména Máchy, v jistém smyslu navázal, nicméně zcela jiným a hlavně nikoliv separátním způsobem. Reagoval tak i na požadavek obnovy českého jazyka, který se pravidelně objevoval v alumnátním časopise „Cyrill a Method“, jehož spoluredaktorem byl Dudíkủv blízký přítel, olomoucký kanovník a prelát Hynek Artur baron Königsbrunn (†1880), jak dokládá část $\mathrm{z}$ dochované vzájemné korespondence.

Dudík svou učebnicí sledoval zejména dva cíle: chtěl se vyhnout hutným a tím pro výuku spíše nevhodným odborným knihopisům ${ }^{15}$ a nahradit je stručnějším výkladem $k$ vývoji českého jazyka, soupisem základního knihopisu a nástinem doby podle zvolených vývojových etap v chronologickém nástinu. Současně hodlal nabídnout studentům na příkladu literárního knihopisu smysl a cíle českého národního hnutí a jazykově obrozeneckých snah na Moravě, jak je patrné ponejvíce v samotném závěru zamýšlené učebnice. Výsledkem tak měl být kompromis mezi hutným knihopisem Josefa Jungmanna $(1773-1847)^{16}$ a podstatně stručnější Palackého soudobou studií o dějinách české literatury, která však dlouho zůstávala jen v rukopise. ${ }^{17}$ Současně měla učebnice poodhalit hlavní Dudíkovy inspirační zdroje, ${ }^{18}$

12 K němu blíže: BRANDL, Vincenc, 1883. Život Josefa Dobrovského. Brno: Matice moravská, 296 s. MACHOVEC, Milan, 2004. Josef Dobrovský (studie s ukázkami z díla). Praha: Akropolis, 256 s., HANUŠ, Jiří, 2008. Osvícenský učenec. Př́klad Josefa Dobrovského. In: MALÍŘ, Jiří a kol., eds. Člověk na Moravě ve druhé polovině 18. století. Brno: CDK, s. 104-116.

13 K němu blíže: VYCHODIL, Pavel Julius, 1898. František Sušil. Životopisný nástin. Brno: Papežská knihtiskárna bened. rajhradských, 379 s., BENEŠ, Josef, 1964. Ač zemřeli, ještě mluví. Medailony českých katolických vlasteneckých kněži. Praha: Ústřední církevní nakladatelství, s. 202-210, ZOBAČOVÁ, Andrea a FROLCOVÁ, Věra, 2004. Sušilova družina a její korespondence v archivním fondu Benediktini Rajhrad. In: František Sušil (1804-1868). Odkaz a inspirace. Rousínov: Město Rousínov, s. 39-50.

${ }^{14}$ K němu blíže: KABELÍK, Jan, ed., 1910. Korrespondence a zápisky Jana Helceleta. Brno: Matice moravská, 661 s.; SOUŠEK, Josef, 1937. MUDr. Jan Helcelet. Edice: Buditelé a průkopníci, sv. 12. Brno: Moravský legionár̆, $38 \mathrm{~s}$.

15 Zejména vyčerpávajícímu, jinak velmi populárnímu knihopisu Jungmannovu (JUNGMANN, Josef, 1825. Historie literatury české aneb Soustavný přehled spisů českých, s krátkou historií národu, osvícení a jazyka. Praha: A. Straširypka).

${ }^{16}$ K němu blíže: SAK, Robert, 2007. Josef Jungmann. Život obrozence. Praha: Vyšehrad, 313 s.

${ }^{17}$ PALACKÝ, František - MACHÁČEK, Karel Simeon: Geschichte der schönen Redekünste bei den Böhmen. (1827). - Tiskem byla vydána až v roce 1968 péčí Oldřicha Králíka a Jiřího Skaličky (Geschichte der schönen Redekünste bei den Böhmen. Déjiny české slovesnosti. Ostrava: Profil, 178 s.).

18 TOMEK, Václav Vladivoj, 1843. Děje země české. Malá encyklopedie nauk. Díl II. Praha: České museum, 339 s.; PALACKÝ, Franz, 1836-1842. Geschichte von Böhmen. Grösstentheils nach Urkunden und 
pomineme-li také souběžně vyvíjené Šemberovy snahy o vytvoření podobné učebnice, jejíž několik archů měl rajhradský benediktin přechodně k dispozici.

Dudík svůj rukopis musel dokončit nejpozději v roce 1847, nebot' již k 27. červenci 1847 nese jeden $\mathrm{z}$ exemplářů razítko a podpis úspěšného cenzurního řízení v Praze. Nicméně jiný $\mathrm{z}$ dochovaných exemplářů je datován až v roce 1848 a liší se pouze po formální stránce. Celkem se totiž dochovaly dva rukopisné exempláře zamýšlené učebnice, přičemž každý z nich disponuje odlišným názvem. Jeden exemplár̆ nese název Přehled literatury českoslovanské ${ }^{19}$ druhý rajhradský exemplář název Stručná historie Literatury české. Sestavil Dr. Beda Dudik. ${ }^{20}$ Až na nepodstatné rozdíly se jedná o týž zamýšlený spis. Jeden rukopis, jak bylo již uvedeno, byl zaslán k cenzurnímu řízení do Prahy, zatímco druhý rukopis byl dedikován rajhradskému opatovi Viktoru Šlosarovi (1793-1854) ${ }^{21}$ a měl patrně zůstat v rajhradském klášteře. To nebylo náhodné, nebot' Šlosar Dudíka podporoval v jeho studijním i následném pedagogickém snažení již od dob jeho noviciátu. ${ }^{22}$

Pokud nahlédneme do Dudíkova rukopisu zamýšlené učebnice, zjistíme, že z koncepčního hlediska uplatnil tradiční chronologický, časově perspektivní přístup k dějinám, rozčleněný stanovenými periodizačními mezníky. V každém z vymezených období ještě vyčlenil dílčí tematické části popisu, kterými byla část dějepisná (,stav politický“), filologická (,stav jazyka“) a literárněhistorická s nejdůležitějším knihopisem (,stav literatury“). V tomto členění nacházíme patrnou paralelu k hutnému literárnímu knihopisu jazykovědce Josefa Jungmanna. Nutno ovšem předeslat, že Dudík se věnoval pouze česky psané literatuře, čímž opomněl a patrně záměrně - řadu mnohých domácích publikací z pera jazykově jiných, především německých autorů $v$ Čechách a na Moravě. Vzhledem ke zvolenému názvu a tím i předeslanému obsahu je to však pochopitelné. Je to zároveň jeden z dokladů tehdejšího Dudíkova upřímného zanícení českým národním hnutím i slovanstvím, které po roce 1849 postupně vymizelo z jeho prací i prezentovaných názorů, po trpké osobní zkušenosti $\mathrm{z}$ průběhu revoluce $\mathrm{v}$ Brně $\mathrm{i} v$ souvislosti $\mathrm{s}$ jeho následným aktivním působením $\mathrm{v}$ jazykově německém brněnském Historickém spolku ${ }^{23}$ a v souvislosti $\mathrm{s}$ dalšími pracovními zadáními ze strany ústředních orgánů rakouské státní administrativy. Rajhradský spis obsahuje celkem šest základních časově vymezených kapitol. Každá z nich je dále rozčleněna podle vytvořené šablony na tř̌i výše jmenované podčásti, pod nimiž se skrývají dílčí tematické kapitoly

\footnotetext{
Handschriften. Bd. 1-2. Prag: G. H. Söhne, týž, 1829, 1830. Würdigung der alten böhmischen Geschichtsschreiber. Prag, JUNGMANN, Josef: cit. dílo.

${ }_{19}$ DUDÍK, Beda. Přehled literatury českoslovanské. Fond E6, inv. č. 1953, sign. Dm 3/3a-4, ka 163, 115 ff. MZAB, Brno.

${ }^{20}$ Týž: Stručná historie Literatury české. Sestavil Dr. Beda Dudik. KBOR, rkp. R 690 (F/K.I.d.25), váz., 163 s. Muzeum Brněnska, Brno.

${ }^{21}$ Též jako Victor Schlossar. - K opatům kláštera v 18. a 19. století např.: HEILANDOVÁ, Lucie, 2014. Rajhradský klášter v době prvních opatů. In: HAVEL, Dalibor a kol., eds. An vědy a umění miloval. Milovníci a mecenáši věd a umění v řeholním rouše. Katalog k výstavě. Brno: Masarykova univerzita + MZK, s. 61-66, 125-128, 180-183.

${ }^{22}$ Bliže: ŠIMKOVÁ, Ema, 2018. Život a osobnost Bedy Dudika (1815-1890) pohledem jeho deníků. Olomouc: Univerzita Palackého, s. 150-157, 165.

${ }^{23}$ Historisch-statistische Sektion der K. k. mährisch-schlesischen Gesellschaft zur Beförderung des Ackerbaues, der Natur- und Landeskunde (1849-1895).
} 
(,mluvozpyt“, „básnictvi““, „historie a zeměpis“, „země a národopis“, „právnictví“ a „bohoslovi“").

Učebnici uvozuje předmluva k vlastnímu obsahu, strukturovanému do pěti tematických bloků, které zároveň symbolizují rozvržení i koncepční uchopení učebnice a především obecné souvislosti vývoje středoevropského prostoru, včetně státně politického postavení Slovanů a vývoje českého jazyka. Chronologicky řazený vývoj od nejstarších časů až do současnosti (do poloviny 19. století) Dudík představil pomocí šesti periodizačních mezníků (léta 450, 1306, 1400/1410, 1526, 1620 a 1780), očividně převzatými z jím kompilovaných publikací od Josefa Jungmanna a Františka Palackého.

Jak se ukázalo, největší překážkou zpř́stupnění Dudíkovy učebnice tiskem byl její jednoznačně kompilační charakter. Pro Dudíka to nepředstavovalo problém, právě pro její zamýšlený didaktický a osvětově propagační účel. Ostatně, tak to také vyličil v úvodu svého rukopisu, který měl sloužit studentům. Koncipování učebnice tudíž nepojal jako vytváření původního odborného díla, a proto předpokládal, že autoři jím kompilovaných prací (Josef Jungmann, František Palacký, Václav V. Tomek, ${ }^{24}$ Pavel J. Šafařík ${ }^{25}$ ) účel jím vytvořené učebnice pochopí a jeho úsilí ocení jako vlastenecký počin pro širší vzdělávání mládeže na Moravě. Bohužel se tak nestalo a Dudík se s některými z nich následně dostal do konfrontací. Zatímco Josef Jungmann nakonec proti kompilování z jeho knihopisu nic podstatného nenamítal, jinak tomu bylo u zmíněných historiků. Na eskalující problém Dudíka upozornil tehdejší redaktor pražského Musejníku, archeolog, historik a básník Jan Erazim Vocel (18021871), ${ }^{26}$ s nímž se Dudík korespondenčně seznámil v roce 1845 při publikování vlastního př́spěvku v Musejníku ${ }^{27}$ i na základě Vocelova publikování vlastenecké poezie a statí o potřebě českého jazyka a prospěšnosti slovanství v moravských kulturně vlastivědných časopisech. ${ }^{28} \mathrm{Z}$ jejich vzájemné korespondence víme, že Vocel Dudíkův rukopis ještě v roce 1847 četl, ocenil ho jako učebnici a připojil též informaci o Jungmannově souhlasu k záměru publikovat ji v Praze. ${ }^{29}$ Následujícího roku už ale Dudíka informoval, že tento záměr narazil na nesouhlas Františka Palackého i Václava Vladivoje Tomka, podle kterých se jednalo

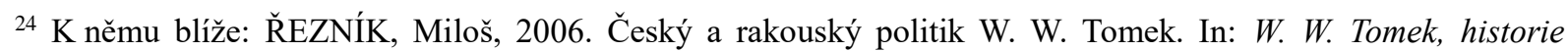
a politika (1818-1905). Sborník př́spěvků královéhradecké konference k 100. výročí úmrtí W. W. Tomka. Pardubice: Univerzita Pardubice, s. 31-57; JIROUŠEK, Bohumil, 2005. Historické myšlení Wácslawa Wladiwoje Tomka. In: JIROUŠEK, Bohumil a kol., eds. Jaroslav Goll a jeho žáci. České Budějovice Pelhřimov: Jihočeská univerzita + Historický ústav, s. 151-163.

${ }^{25} \mathrm{~K}$ němu blíže: HANUŠ, Josef, 1895. Pavel Josef Šafařík v životě i spisích. Ke stoletým narozeninám jeho. Matice lidu 29, sv. 6, č. 174, 208 s., MERHAUT, Luboš a kol., 2008. Lexikon české literatury. Osobnosti, dila, instituce. Díl: 4/I. (S-T). Praha: Academia, s. 521-531.

${ }^{26}$ K němu blíže: SKLENÁŘ, Karel, 1981. Jan Erazim Vocel. Edice: Odkazy pokrokových osobností naší minulosti, sv. 61. Praha: Melantrich, 432 s.

${ }^{27}$ DUDÍK, Beda, 1845. Smlouva, kteráž se stala mezi císařem Rudolfem a Matyášem arciknížetem rakouským v ležení polním mezi Štěrboholy a dolními Měcholupy léta 1608. Časopis Českého Museum 19, č. 2, s. 292-308. ${ }^{28}$ Jednalo se o stati Über den gegenwärtigen Zustand der slavischen Literatur in Böhmen, Mähren und Ungarn (1838), Wichtigkeit der böhmischen Sprache für den böhmischen und mährischen Adel (1839) a Die materiellen Kulturfortschritte des slavischen Volkes in Böhmen und Mähren (1839).

${ }^{29}$ Dopis J. E. Vocela B. Dudíkovi, datovaný 7. 5. 1847 v Praze. Fond E6, sign. Dm 3/2a-208, ka 153, f. 741. MZAB, Brno.
} 
víceméně o výtah z Jungmannova knihopisu. ${ }^{30}$ Jestliže v předchozím dopise s Dudíkovým záměrem ještě souhlasil, nyní se připojil k oponentům Dudíkova záměru. Z tónu dopisu bylo patrné, jak značná už tehdy byla Palackého autorita, jíž se ochotně podřídil také Vocel. Dudík se vzápětí zřejmě obrátil přímo na sekretáře Matice české Václava V. Tomka, jak dosvědčuje další z Vocelových dopisů Dudíkovi. Vocel rukopis podle Dudíkova přání Tomkovi předal, aby se přesto zasadil o jeho vydání tiskem u Matice české v Praze, ale dodal k tomu, že př́ípadné otištění beztak posoudí až matiční výbor. ${ }^{31} \mathrm{Z}$ jiného Dudíkova dopisu Vocelovi se dozvídáme, že se nadále pokoušel rozptýlit Vocelovy pochybnosti a znovu mu vysvětloval potřebu kompilačního charakteru svého rukopisu. Podobně se nařčením z plagiátorství pokoušel hájit ve svém dopisu pražskému knihovníku Václavu Hankovi (1791-1861) ${ }^{32}$ do Prahy. Největší nepochopení podle očekávání projevil František Palacký, sám u sebe uvyklý nezbytné preciznosti a důkladnosti historiografické práce. Vocel o tom Dudíka opět informoval, což rajhradského benediktina přimělo po jistém váhání Palackému napsat a celou situaci mu separátně vysvětlit, včetně toho, proč kompiloval zrovna z jeho publikace, dále z Tomkova přehledu dějin, z Šemberových zapůjčených archů, z Jungmanna i z Šafaříka. ${ }^{33}$ V závěru pak dodal, že svůj rukopis nemá v úmyslu přepracovat, nebot' je to pouhá učebnice a nikoliv odborné dílo a navíc se beztak aktuálně věnuje odbornému vypsání dějin rajhradského kláštera na Moravě. ${ }^{34}$ Výsledkem tak byla skutečnost, že Dudíkův rukopis avizované učebnice nebyl nikdy vydán tiskem a rajhradský benediktin jej poměrně záhy odložil stranou, jakmile tiskem vyšly jiné, kvalifikovanější jazykové příručky a zejména po svém odchodu $\mathrm{z}$ moravského školství, aby se naplno věnoval moravské historiografii a archivnictví. Pro úplnost dodejme, že jeho rukopis učebnice českého jazyka nebyl jediným didaktickým př́spěvkem k tehdejšímu jazykovému obrozování, který vznikl v dané době ,za zdmi“ rajhradského kláštera. Nedlouho po Dudíkovi, v roce 1849, si podobný rukopis vytvořil benediktin a pedagog stejného ústavu (Vyššího gymnázia v Brně) a pozdější opat rajhradských benediktinů Vintír Kalivoda $(1815-1883) .{ }^{35}$ Také on nejprve učil na Filozofickém ústavu v Brně a poté na německém gymnáziu. Jeho rukopis, opřený výhradně o Jungmannův knihopis, však ve srovnání s Dudíkovým nedosáhl stejné kvality a navíc byl obsahově výrazně stručnější. Kromě toho Kalivoda, nebot' nikdy nepůsobil jako historik a neprováděl ani archivářské činnosti, prakticky zcela pominul historické souvislosti politického vývoje země a věnoval se pouze lingvistice, dějinám literatury a soudobému stavu jazyka. Na straně druhé, ke svému výkladu připojil řadu citací a ukázek z českých literárních

\footnotetext{
${ }^{30}$ Dopis J. E. Vocela B. Dudíkovi, datovaný 1. 2. 1848 v Praze. Tamtéž, f. 742. MZAB, Brno.

${ }^{31}$ Dopis J. E. Vocela B. Dudíkovi, datovaný 1. 3. 1848 v Praze. Tamtéž, f. 743. MZAB, Brno.

${ }^{32}$ K němu blíže: HANUŠ, Josef a kol., 1911. Literatura česká devatenáctého století. Díl 1.: Od Dobrovského k Jungmannově škole básnické. Praha: Laichter, 2. vyd., s. 719-785; SRŠEŇ, Lubomír, 2009. Příspěvky k poznání osobnosti Václava Hanky. In: Acta Musei Nationalis Pragae. Series A - Historia, sv. 63, č. 1-4, s. 1168.

33 ŠAFǍ̌́IK, Pavel Josef, 1837. Slowanské starožitnosti. Oddíl dějepisný. Praha: České museum, 1005 s.

${ }^{34}$ Dopis B. Dudíka Fr. Palackému, datovaný 1. 5. 1849 v Brně. Fond František Palacký, sign. 14/M/33. Památník Národního písemnictví, Literární archiv (Strahovský klášter), Praha.

35 Též jako Günther Kalivoda. - KALIVODA, Günther: Historie řeči a literatury české. 1849, váz. rkp., 82 ff. KBOR, rkp. R 692 (F/K.I.d.26). Muzeum Brněnska, Brno.
} 
dějin, čímž jeho rukopis místy dostal podobu jakési knižní antologie. Na rozdíl od Dudíka však Kalivoda patrně nikdy neplánoval otištění svého rukopisu. Sloužil mu pouze jako interní pomůcka vlastním hodinám českého jazyka a literatury na brněnském vyšším gymnáziu.

Pro kontext tehdejšího Dudíkova jazykovědného snažení ještě musíme dodat, že český jazyk se úspěšně vyučoval již v Olomouci, a to nejprve na Stavovské akademii (profesory češtiny zde byli Antonín Boček, pozdější zemský archivář a historiograf, a zmíněný Alois V. Šembera, zemský archivář v letech 1847-1849) a následně i na Císařsko-královské Františkově univerzitě, když zde byla otevřena katedra českého jazyka. V roce 1848 se na katedře chopil výuky národního jazyka vzděláním lékař a novinář Jan Helcelet, jemuž základní materiálovou i metodickou podporu poskytl opět A. V. Šembera.

Pokud máme Dudíkovu snahu o sestavení jazykové učebnice zhodnotit, pak je třeba uvést, že se tehdy $\mathrm{v}$ prrípadě Moravy jednalo o víceméně ojedinělý pokus navázat na podobný obrozenecký proces v sousedních Čechách a souběžné vyjádření sympatií k tamějšímu rozvíjejícímu se českému národně emancipačnímu programu i $\mathrm{k}$ čerstvě představené Palackého koncepci českých národních dějin. V př́padě rukopisného návrhu učebnice se jedná o ústrojný bilanční přehled chronologického dějepisu, vývoje národního jazyka a literatury a dochovaného knihopisu $\mathrm{z}$ daného období, podle př́kladu podobně koncipovaných učebnic v sousedních Čechách, kde již bylo jazykovědné a literárněhistorické bádání v uvážlivém rozpuku a postaveno na kvalitativně vyšší úroveň, než tomu bylo zatím na Moravě. ${ }^{36}$ Do koncepční podoby Dudíkovy učebnice se především promítla skutečnost, že on sám byl pedagogem jak dějepisu a zeměpisu, tak i českého jazyka, a proto na všechny disciplíny, jejichž prizmatem vývoj jazyka sledoval, nahlížel stejně závažnou optikou. Představené poznatky a výsledky ve výkladu spojil a zkombinoval do stručného výkladu ke každé vybrané kapitole. Již při jiné př́iležitosti jsem upozornil na význam Dudíkových interpretací vybraných dějepisných událostí v této učebnici. Především byly výrazně ovlivněny rozvíjejícím se českým národním hnutím, které po jistou dobu podporoval, a dále módním slovanstvím (v letech 1840-1850). ${ }^{37}$ Teprve proměna osobního smýšlení po revoluční zkušenosti let 1848-1849 zapříčinila opětovný př́iklon k zemskému patriotismu a ke

\footnotetext{
${ }^{36}$ Stačí zmínit některé v Čechách vydané publikace $\mathrm{k}$ propagaci a výuce českého jazyka, byt' stále trvaly spory o správné pojetí české gramatiky: NEJEDLÝ, Johann, 1804. Praktische böhmische Grammatik. Prag; HANKA, Václav, 1817. Pravopis český podle základu gramatiky Dobrovského. Praha: B. Haase, 96 s.; týž, 1831. Grammatika, čili Mluvnice českého jazyka podle Dobrovského. Praha; MACHÁČEK, Simeon Karel, 1830. Bömische Chrestomathie für Deutsche. Mit Erläuterungen und einem vollständigen Wörterbuch. Prag, $271+125$ s., ZIEGLER, Josef Liboslav, 1845. Deutschbömische Sprachlehre zum Gebrauche d. Schuljugend. Časlau: Váša; JUNGMANN, Josef, 1845. Slovesnost aneb Sbirka přikladů s krátkým pojednáním o slohu. Praha: J. Spurný, 836 s.; VLASÁK, Josef Věnceslav, 1848. Böhmische und Deutsche Sprachlehre in Beispielen, insbesondere für Diejenigen, welche die eine oder die andere Sprache leicht erlernen. Mit einer beigefügten kurzen Geschichte Böhmens. Prag: J. Pospischil, 215 s., TOMEK, Václav Vladivoj, 1848. Kurzgefasste böhmische Sprachlehre für Böhmen. Prag: J. Calve, $86 \mathrm{~s}$.

${ }^{37}$ Bliže: MAHEL, Richard, 2008. „Študující mládeži a wšem milým krajanům...“. První podání českých dějin Františka Bedy Dudíka $\mathrm{v}$ jeho rukopisu $\mathrm{k}$ dějinám české literatury z roku 1848. Část 1-2. Vlastivědný věstník moravský 60, č. 3, s. 269-278, č. 4, s. 345-358.
} 
klerikálnímu konzervatismu, zcela v intencích tzv. Sušilovy družiny, ale také částečnou akceptaci multinacionální odnože rakušanství. To už je však jiná kapitola Dudíkova života.

Dudíkův pokus o sestavení učebnice českého jazyka z roku 1847 musíme proto chápat jako dobový exemplární projev národně orientované buditelské činnosti nižšśího moravského kléru. Jedním z prvních plánovaných kroků obrozenců tudíž mělo být znovuzavedení výuky českého jazyka do elementárního a navazujícího školství v Čechách a na Moravě ${ }^{38}$ a následně prosazení češtiny také do úřední komunikace habsburského soustátí. V př́padě Bedy Dudíka to nebyl jediný projev jeho sympatií k českému národnímu hnutí a jazykovému obrození. $\mathrm{V}$ té době vydal česky (a v českém odborném periodiku) jeden ze svých mnoha popularizačních př́spěvků věnovaných českým a moravským dějinám. Lze to považovat za určitou výjimku, nebot' zpravidla dával přednost tisku v jazykově německých kulturně-osvětových časopisech na Moravě, vzhledem $\mathrm{k}$ tamějším příznivějším možnostem publikování. To mimo jiné dokládá i další skutečnost, totiž že Dudík jako pedagog už v této době silně inklinoval ke zkoumání regionální historie, aniž ještě tušil, že se nakonec pedagogiky zcela vzdá právě ve prospěch historické vědy (v letech 1855-1856) a tou se nakonec proslaví. ${ }^{39}$ Dudík si byl vědom, že št'astná budoucnost Moravy spočívá především v pečlivé a správné výchově mládeže, kterou je třeba vést ke vzdělání, lásce $\mathrm{k}$ vlasti, ale také $\mathrm{k}$ poněkud opomenutému českému jazyku. A to přesto, že si uvědomoval, že Morava je vlastně zemí dvojí národnosti i jazyka, zemí velkých urbanistických i sociálních rozdílů, zemí lokálních tradic a významně dlouhé náboženské, cyrilometodějské tradice. Přestože se Beda Dudík nijak významněji nezapsal do hlubších análů moravské pedagogiky 19. století, neznamená to, že v ní nezanechal žádné stopy. Na jeho působení s odstupem času ráda vzpomínala řada jeho žáků, z nichž někteří se stali významnými osobnostmi své doby. ${ }^{40}$ Jeho hodiny českého jazyka a literatury byly ve své době hojně navštěvovány, byly oblíbené a svým dílem přispěly $\mathrm{k}$ rozvoji vědomí príslušnosti $\mathrm{k}$ dosud menšinovému proudu českého národního hnutí na Moravě. Nemělo by též zapadnout, že Dudík významně obohatil školní knihovnu původního Filozofického ústavu o soudobé slovanské literární i odborné texty. Ačkoliv se nakonec věnoval spíše historické vědě, kterou daleko více proslul, jeho pedagogika měla $\mathrm{v}$ jistém smyslu nejen svou dynamiku (vzpomeňme jeho zápas o realizaci výuky s konzervativně smýšlejícím biskupským ordinariátem či jeho nevšední přednášky z biblických dějin), ale nakonec i svou nutnou kontinuitu. Po dvě léta totiž po svém odchodu z gymnázia přednášel studentům historických oborů na vídeňské univerzitě jako soukromý docent pro studium středověkých písemných pramenů o pomocných vědách historických a o významu

\footnotetext{
${ }^{38} \mathrm{~K}$ závažnosti i k problematičnosti tohoto záměru blíže např.: HANZAL, Josef, 1968. Jazyková otázka ve vývoji obrozenského školství. Čs ČH 16, č. 3, s. 317-340.

${ }^{39} \mathrm{~K}$ tomu blíže: MAHEL, Richard, 2011. K počátkům vědecké činnosti rajhradského benediktina a moravského historika Františka Bedy Dudíka (1815-1890). Ke 120. výročí úmrtí historiografa Moravy. Vlastivědný věstník moravský 63, č. 2, s. 105-119.

${ }^{40}$ Např. budoucí významný lékař, botanik a cestovatel rytír Jindřich Blažej Vávra / Heinrich Wawra Ritter von Fernsee/ (1831-1887), účastník císařské brazilské expedice arcivévody Maxmiliána Habsburského (1859-1860), dále objevitelské výpravy kolem světa v letech 1868-1871 a autor nově popsaných 173 botanických druhů.
} 
středověkých rukopisů pro moderní dějepisnou práci. Tak jako mnozí jiní učitelé své doby, i on jako benediktinský kněz a učitel svým malým dílem přispěl k rozvoji moravského školství první poloviny 19. století, na které pak mohla navázat nová generace pedagogů, převážně již civilních zaměstnanců (odchovanců národně vlasteneckých školských ústavů) nebo ještě původních teologických alumnátů. Neměli bychom tedy zapomínat, že Beda Dudík byl nejen významný historik, archivář a autor mnoha historiografických tisků, ale v mládí také národně orientovaný pedagog, kterému nebylo nic moravského cizí.

\section{Archivní a primární zdroje}

Dekret datovaný 22. 3. 1846 v Brně, podeps. V. Tálským. Fond E6 (Benediktini Rajhrad), inv. č. 1947, sign. Dm 3/1 6, ka. 151, f. 10. MZAB, Brno.

Dekret datovaný 28. 12. 1845 v Brně, podeps. V. Tálským. Fond E6 (Benediktini Rajhrad), inv. č. 1947, sign. Dm 3/1 6, ka. 151, f. 9. MZAB, Brno.

Dopis A. Hrušky B. Dudíkovi, datovaný 5. 12. 1847 v Hradci Králové. Fond E6, inv. č. 1948, sign. Dm 3/2a-94, ka. 153, f. 391. MZAB, Brno

Dopis B. Dudíka Fr. Palackému, datovaný 1. 5. 1849 v Brně. Fond František Palacký, sign. 14/M/33. Památník Národního písemnictví, Literární archiv (Strahovský klášter), Praha.

Dopisy J. E. Vocela B. Dudíkovi, datované 7. 5. 1847, 1. 2. a 1. 3. 1848 v Praze. Fond E6, sign. Dm 3/2a 208, ka. 153, f. 741-743. MZAB, Brno.

DUDÍK, Beda: Stručná historie Literatury české. Sestavil Dr. Beda Dudík. 1848, váz., 163 s. Knihovna benediktinského opatství Rajhrad, rkp. R 690 (F/K.I.d.25). Muzeum Brněnska, Brno.

Fond E6 (Benediktini Rajhrad). Osobní pozůstalost Bedy Dudíka (sign. Dm 3/1-6, ka 151, sign. Dm 3/2a-94, ka 153, sign. Dm 3/2a-208, ka 153, sign. Dm 3/3a-4, ka 163). Moravský zemský archiv, Brno.

KABELÍK, Jan, ed., 1910. Korrespondence a zápisky Jana Helceleta. Edice: Prameny dějin moravských č. 1. Brno: Historická komise při Matici moravské, $661 \mathrm{~s}$.

KALIVODA, Günther: Historie řeči a literatury české. 1849, váz. rkp., 82 ff. Knihovna benediktinského opatství Rajhrad, rkp. R 692 (F/K.I.d.26). Muzeum Brněnska, Brno.

\section{Literatura}

BENEŠ, Josef, 1964. Ač zemřeli, ještě mluví. Medailony českých katolických vlasteneckých kněží. Praha: Ústřední církevní nakladatelství, s. 202-210.

DUDÍK, Beda, 1845. Smlouva, kteráž se stala mezi císařem Rudolfem a Matyášem arciknížetem rakouským v ležení polním mezi Štěrboholy a dolními Měcholupy léta 1608. Časopis Českého Museum 19, č. 2, s. 292-308.

HANUŠ, Jiří, 2008. Osvícenský učenec. Př́iklad Josefa Dobrovského. In: MALÍŘ Jiří a kol., eds. Člověk na Moravě ve druhé polovině 18. století. Brno: CDK, s. 104-116. ISBN 978-807325-175-8. 
HANUŠ, Josef a kol., 1911. Literatura česká devatenáctého století. Díl 1.: Od Dobrovského k Jungmannově škole básnické. Praha: Laichter, 2. vyd., s. 719-785.

HANZAL, Josef, 1968. Jazyková otázka ve vývoji obrozenského školství. Československý časopis historický 16, č. 3, s. 317-340.

HEILANDOVÁ, Lucie, 2014. Rajhradský klášter v době prvních opatů. In: HAVEL, Dalibor a kol., eds: An vědy a umění miloval. Milovníci a mecenášsi věd a umění v řeholním rouše. Katalog k výstavě. Brno: Masarykova univerzita + MZK, s. 61-84. ISBN 978-80-210-6799-8. JIROUŠEK, Bohumil, 2005. Historické myšlení Wácslawa Wladiwoje Tomka. In: JIROUŠEK, Bohumil a kol., eds. Jaroslav Goll a jeho žáci. České Budějovice - Pelhřimov: Jihočeská univerzita + Historický ústav, s. 151-163. ISBN 80-7040-780-8.

JUNGMANN, Josef, 1825. Historie literatury české aneb Soustavný přehled spisů českých, s krátkou historii národu, osvicení a jazyka. Praha: A. Straširypka.

KÁRNÍK, Zdeněk, 1998. Konzervativní sociální zdroje supraetnického rakušanství a předlitavského supranacionalismu. In: K novověkým sociálním dějinám českých zemí. Díl 2: Z dob rakouských a předlitavských, 1848-1918. Praha: Karolinum, s. 49-85. ISBN 80-7184496-9.

KOŘALKA, Jiří, 2006. Rodem Moravan, národem Čech. František Palacký. In: JAN, Libor a DRAHOŠ, Zdeněk, eds. Osobnosti moravských dějin (1). Brno: Matice moravská, s. 309329. ISBN 80-86488-38-1.

MAHEL, Richard, 2015. Beda Dudík (1815-1890). Život a dílo rajhradského benediktina a moravského zemského historiografa ve světle jeho osobni pozůstalosti. Praha: Národní archiv. ISBN 978-80-7469-028-0.

MAHEL, Richard, 2011. K počátkům vědecké činnosti rajhradského benediktina a moravského historika Františka Bedy Dudíka (1815-1890). Ke 120. výročí úmrtí historiografa Moravy. Vlastivědný věstník moravský 63, č. 2, s. 105-119. ISSN 0323-2581.

MAHEL, Richard, 2018. „Pilně snáším stavivo $\mathrm{k}$ př́iští budově, jako učitel mám $\mathrm{k}$ tomu př́ležitostí dost“". K pedagogickému působení rajhradského benediktina Bedy Dudíka v Brně (1841-1854) v čase vzepětí českého národně emancipačního hnutí. In: KAŠPÁRKOVÁ, Šárka a kol., eds. Morava v době prevrati̊ a změn 1848-1918. Sborník př́spěvků z mezinárodni odborné konference, Kroměříž, 6. a 7. června 2018. Kroměříž: Knihovna Kroměřížska, s. 91-105. ISBN 978-80-86759-10-4.

MAHEL, Richard, 2017. Střetávání zemského patriotismu, národně orientovaného vlastenectví a multinacionálního státního patriotismu v korespondenci a v odborném díle moravského historika Bedy Dudíka. In: Laudatio PhDr. Evě Ryšavé. Příspěvky k životnímu jubileu. Acta Musei Nationalis Pragae, Historia litterarum 62, č. 1-2, s. 26-40. ISSN 25706861.

MAHEL, Richard, 2008. „Študující mládeži a wšem milým krajanům...“. První podání českých dějin Františka Bedy Dudíka v jeho rukopisu k dějinám české literatury z roku 1848. Část 1-2. Vlastivědný věstník moravský 60, č. 3, s. 269-278, č. 4, s. 345-358. ISSN 03232581. 
MERHAUT, Luboš a kol., 2008. Lexikon české literatury. Osobnosti, díla, instituce. Díl: 4/I. (S-T). Praha: Academia, s. 521-531. ISBN 978-80-200-1572-3.

PALACKÝ, Franz, 1836-1842: Geschichte von Böhmen. Grösstentheils nach Urkunden und Handschriften. Bd. 1-2. Prag: G. H. Söhne.

POKORNÝ, Václav Jan, 1922. Beda Dudík zahajuje přednášky o české literatuře v Brně roku 1846. Archiv literárni: prameny dějin české literatury katolické: přiloha $k$ revui Archa. Olomouc: Družina literární a umělecká. Sv. II, s. 201-204.

ŘEZNÍK, Miloš, ed., 2006. Český a rakouský politik W. W. Tomek. In: W. W. Tomek, historie a politika (1818-1905). Sborník příspěvků královéhradecké konference k 100. výročí úmrtí W. W. Tomka. Pardubice: Univerzita Pardubice, s. 31-57. ISBN 80-7194-884-5.

SAK, Robert, 2007. Josef Jungmann. Život obrozence. Praha: Vyšehrad, 313 s. ISBN 978-807021-890-7.

SRŠEŇ, Lubomír, 2009. Př́ispěvky k poznání osobnosti Václava Hanky. In: Acta Musei Nationalis Pragae. Series A - Historia, sv. 63, č. 1-4, s. 1-168. ISSN 0036-5335.

ŠIMKOVÁ, Ema, 2018. Život a osobnost Bedy Dudika (1815-1890) pohledem jeho deníki̊. Olomouc: Univerzita Palackého, 334 s. ISBN 987-80-87895-83-2.

SKLENÁ̌̆, Karel, 1981. Jan Erazim Vocel. Edice: Odkazy pokrokových osobností naší minulosti, sv. 61. Praha: Melantrich, $432 \mathrm{~s}$.

ZOBAČOVÁ, Andrea, 2004. Sušilova družina a její korespondence v archivním fondu Benediktini Rajhrad. In: FROLCOVÁ, Věra, ed. František Sušil (1804-1868). Odkaz a inspirace. Rousínov: Město Rousínov, s. 39-50. ISBN 80-85010-65-8. 